\title{
COASTAL EVOLUTION AND SEDIMENT SUCCESSION OF SRI LANKA: A REVIEW ON QUATERNARY SEA LEVELS, CLIMATES AND SEDIMENTATION PROCESSES
}

\author{
A.M.N.M. ADIKARAM ${ }^{1 *}$, H.M.T.G.A. PITAWALA ${ }^{2}$, D.T. JAYAWARDANA ${ }^{3}$ \\ ${ }^{1}$ Department of Physical Sciences, Faculty of Applied Sciences, South Eastern University, \\ Sri Lanka \\ ${ }^{2}$ Department of Geology, Faculty of Science, University of Peradeniya, \\ Sri Lanka \\ ${ }^{3}$ Department of Forestry and Environmental Science, Sri Jayawardhanapura University, \\ Sri Lanka \\ *Corresponding Author Email: maduryaa@gmail.com
}

(Received 23 ${ }^{\text {rd }}$ July 2018; Accepted $20^{\text {th }}$ October 2018)

\begin{abstract}
In spite of the small size, the coastal environments of the four cardinal quadrants of Sri Lanka indicate different morphologies and evolutionary characteristics. Therefore, a review of the coastal evolution and sediment succession of Sri Lanka is presented with formal published data and multi-proxy data using modern techniques. The Sri Lankan coasts have provided insightful evidence of paleo-sea level oscillations during the last glacial period and Late-Holocene epoch. The prevailing climate since the last glacial maximum has provided excessive sediment to coastal lowlands and produced Pleistocene sedimentary signatures driven with aeolian and fluvial processes. Major coastal sediment barriers developed during late Holocene transgressions and were modified afterwards. Both northwestern (NW) and southeastern (SE) coastal zones experienced the monsoon rain-shadow effect. In the NW quadrant, the shielding effect of the Indian sub-continent preserved much of the evidence for paleo-sea level oscillations and paleo-climate, although the basement rock is Miocene limestone. In contrast, the rocky crystalline SE coast has less preservation due to its considerable exposure to the wind driven forces. The energy of the of eastward moving currents is higher due to the combined effect of westerly wind bursts (WWB) and SW monsoons, and hence, southwestern (SW) and southern coastal areas show regressive coasts due to current generated coastal processes. However, the eastern zone of the SE quadrant is progressive due to its position in the conjunction zone of the eastward moving sea currents and westward moving lowsalinity water flows of the Bay of Bengal. The pattern of sea currents and monsoon strength controlled the wind driven morphologies of the NE and SW quadrants. Though the geology is similar in the NE and SW quadrants, the general geological strike of the SW coast is parallel to the turning SW monsoon currents and most likely the rock types has supported erosion. Sediment loads generated from NE monsoon and east India coastal currents (EICC) are upwelled with the strong circulations within the Bay of Bengal and deposit on the NE coasts indicating heavy mineral beds that were sorted by swash and backwash activities. This review notes how tropical monsoon induced sea currents and other currents around the Bay of Bengal region are factors in the differences in the geology and structure of coastal morphologies in four quadrants of Sri Lanka. These factors traced/erased the global melting events on a tropical small island during the Quaternary.
\end{abstract}

Key words: Coastal geomorphology, sea current, sea level, Quaternary, Sri Lanka, 


\section{INTRODUCTION AND BACKGROUND}

Quaternary period sea level fluctuations and consequent coastal environmental evolutions are well studied and documented in different regions of the world; yet contradictory data have been obtained from different geographical locations (Angulo et al., 2006, Leonard et al., 2018). Principally, the global active periods of inter and intraglacial events during the Pleistocene and Holocene epochs are recorded as eustatic sea level changes in different coastal regions of altered heights. Records of global glacial melting events are controlled by factors such as the size of the land mass (continental land or island), distance from the melting ice sheets, geographical position in the earth (equatorial region or sub equatorial region) and the rheological structures of each region (Camoin et al., 1997, 2004). Therefore, Quaternary sea level records in regional scales are needed to rectify global inconsistencies.

Except for local lineament adjustments, the Indian Ocean region has remained tectonically stable during the Quaternary period (Curray et al., 2003; Roy and Chatterjee, 2015). The geographical position of tropical zones remain far afield from glacial regions, making the Indian Ocean the best zone to study global melting events in the Quaternary. However, few studies in the literature have recorded these eustatic sea level oscillations in the Indian Ocean region with scientific evidence (Colonna et al., 1996; Hanebuth et al., 2000; Yokoyama et al., 2000; Camoin et al., 2004).

Sri Lanka is located at the tip of the Indian subcontinent and is characterized as a tectonically stable island (Richmond et al., 2006). The Sri
Lankan coastline is approximately $1920 \mathrm{~km}$ long and open to the Indian Ocean (Katupotha, 1988). Limited scientific research and theory-based articles addressing the evolution and Quaternary sea level changes around Sri Lankan coasts have been published, but several aspects are problematic and debatable due to the coastal zone (Weerakkody, 1988; Cooray and Katupotha, 1991; Ranasinghe et al., 2013). Despite Sri Lanka is a small island, preserved coastal morphological features of it provides diverse evidences in the four cardinal quadrants of the island (Cooray and Katupotha, 1991).

Scientific studies on the coastal evolutions and paleo-sea levels of Sri Lankan coasts have increased since the 2004 Indian Ocean tsunami (Goff et al., 2006; Dahanayaka and Kulasena, 2008; Morton et al., 2008; Goto et al., 2011; Ranasinghe et al., 2013). In essence, tsunami deposits further highlighted that the forces governing sedimentation on the each coasts of Sri Lanka are different (Wang et al., 2007; Morton et al., 2008; Goto et al., 2011). The western coast is partially covered by the Indian peninsula, and the rest is directly exposed to the open ocean. In contrast, the eastern coast is exposed to the Bay of Bengal, and remnants of the tectonic settings of Java-Sumatra are preserved in undisturbed environments (Jackson, 2008). Hence, this article reviews the scientific evidence from the island and Indian Ocean region to resolve the sea level records, problematic evolutions and sediment successions of Sri Lankan coasts.

The analysis in this article emphasizes the difference in sedimentary processes on the four cardinal coastal quadrants of Sri Lanka. The results support the ability to reconstruct the effect of global ice sheet melting on small 
islands in tropical regions and subsequent changes during the misinterpretations of global paleoQuaternary period, which can lead to events.

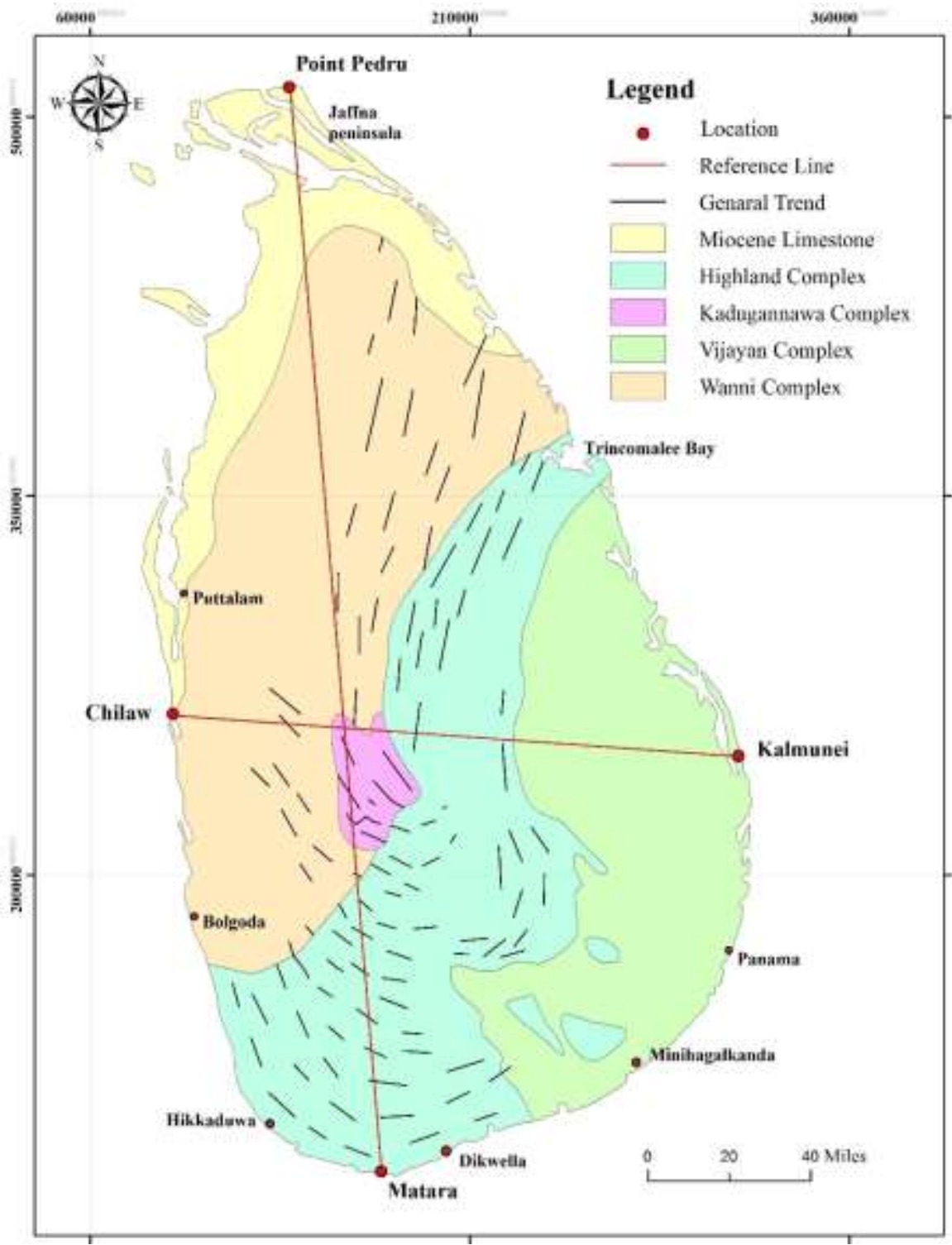

Fig. 1 General geology and structure of Sri Lanka. The reference lines indicate the four cardinal quadrants of this review which having different geological backgrounds and coastal geomorphologies.

\section{BASEMENT OF SRI LANKA}

Sediments generated as a result of weathering and erosion of central hill countries of Sri Lanka may be the main sources for the coastal sedimentations. The Precambrian basement of Sri Lanka is subdivided into four metamorphosed lithtectonic units based to lithology, structure, metamorphic grade, isotopic characteristics and geochronological data (Cooray 1994; Kröner et al., 2003; Kehelpannala, 2003). The NE part of the country is covered by fossiliferous Miocene limestones that were laid on the metamorphic basement (Figure 1; Cooray, 1984; Dahanayake and Jayawardhana, 1979; Katupotha and Dias, 2001). 


\section{QUATERNARY EVOLUTION OF COASTAL MORPHOLOGIES}

Quaternary deposits cover the Precambrian rocks and Miocene limestone around the country with various thicknesses and in different forms traced by erosion and depositional processes of marine, fluvial and aeolian nature (Katupotha, 2007). Further, these quaternary formations belong to either the Pleistocene or Holocene have been formed and modified by regional, local, coastal and climate constraints (Katupotha, 2014).

\section{PLEISTOCENE COASTAL REMARKS AND EVOLUTION}

Around the SE Asian region, approximately 50 glacial cycles have been noted with evidence of biogeography (Woodruff, 2010). However, the Sri Lankan coasts hold evidence of a sea level high stand before the Last Glacial Maximum (LGM) but no scientific evidence to prove an exact time period or additional glacial periods prior to or after that (Swan, 1983; Cooray and Katupotha, 1991). This foremost sea level high stand is recorded as 'basal gravel beds which are composed of quartz, chert and limestone pellets bound by ferruginous materials' (Cooray, 1967). In the NW region of Sri Lanka, 'basal gravel beds' are laid on Miocene limestones or Precambrian basements, their origin proposed as probable fluvial system sheet flood events or a sea level fluctuation (Cooray, 1967; Cooray and Katupotha, 1991). Similarly, in the SE coasts, 'basal ferruginous gravels' that were laid over the Miocene's of Minihagalkanda are suggested to have originated during the Pleistocene, the base of the Quaternary deposits (Figure 1; Weerakkody, 1992).
Sri Lankan coasts are indicative of wet and dry sedimentation processes during the glacial and interglacial periods (Cooray and Katupotha, 1991). Studies around the Indian Ocean indicate that the sea level was approximately $110-130 \mathrm{~m}$ below the present sea level during the LGM period and has gradually increased since (Colonna et al., 1996; Hanebuth et al., 2000; Yokoyama et al., 2000; Camoin et al., 2004; Fürstenau et al., 2010). A Pb isotope evolution study on the Indian Ocean revealed that a warm and wet climate prevailed, enhancing continental chemical weathering processes during the interglacial periods (Wilson et al., 2015). Likewise, weathering processes in Sri Lanka were activated during before the LGM, and huge amounts of sediment were deposited in exposed coastal plains (Cooray and Katupotha, 1991; Katupotha, 1994). Similar to Indian coasts, fluvial and aeolian processes activated from the strong monsoon climate and sea level low stands reworked the coastal plane and brought sediments back to coastal lowlands (Jayangondaperumal et al., 2012). The well-known 'red beds' recorded in the NW and SE coasts developed with such aeolian actions (Dahanayake and Jayawardana, 1979; Cooray and Katupotha, 1991; Weerakkody, 1992). The depositional ages of the NW 'red beds' are calculated as $25000 \mathrm{BP}$, corresponding to the sea level low stands of Sri Lanka (Singhvi et al., 1986). Similarly, the red sand deposits that are found in the east and SE regions of India are more comparable with the NW 'red beds' of Sri Lanka (Gardner, 1995). They also appear to have originated from fluvial and coastal dunes and are located about $+12 \mathrm{~m}$ from the present sea level, indicating the strength of the aeolian processes (Gardner, 1995; Rao et al., 2006). Chronological data from the 
Indian red dunes suggests that they could have been deposited post LGM (Rao et al., 2006; Srivastava et al., 2016).

In Sri Lanka, there are several elevated (approximately $15 \mathrm{~m}$ above mean sea level) gravel deposits, and extensive sandy deposits are found in localized areas in the southern and western coastal regions (Cooray and Katupotha, 1991). The origin of these has been suggested as a result of fluvial processes during a sea level high stand (Deraniyagala, 1958; Wicramarathne et al., 1988; Cooray and Katupotha, 1991; Wijayananda, 1994). Wickramagamage (2011) noted that similar terrace gravels, raised beaches and lagoonal deposits in the elevated localities of Bolgoda Lake and the Kalu Ganga River regions of western Sri Lanka (Figure 1). $\mathrm{He}$ suggested the formation of these deposits is during the sea level high stand period between the LGM and the Holocene. However, the age of the 'terrace gravels' is problematic since sea level high stands are not recorded after the LGM of the Pleistocene period, and hence a previous glacial period is suggested, which requires future studies to confirm.

\section{HOLOCENE COASTAL REMARKS (0.0117 MA - RECENT)}

As a result of the Late Quaternary marine transgressions, most worldwide coastal lagoons and their relevant features have been formed and developed in lowlands or valley mouths (Bird, 1994). Afterward, locally generated coastal processes, sea level changes and climatic actions reshaped the coastal morphologies (Martin and Dominguez, 1994). As described by Camoin et al. (2004) and references therein, there are two types of sea level oscillations identified around the Indian Ocean during the
Holocene. Type I indicates a regressive sea level for the Holocene compared to the present mean sea level, with sediments laid down with LGM (Camoin et al., 2004; Jayangondaperumal, 2014). Type II indicates regressive as well as transgressive events with different increment rates (Brückner, 1989).

The mid to late Holocene period of Sri Lanka is recorded as a sea level high stand or as a transgressive coast corresponding to Type II oscillations (Katupotha and Fujiwara, 1988; Ranasinghe et al., 2013; Ratnayaka et al., 2017). For example, the marine originated fossil shell deposits emerged in coastal embayments of the southern and SE coastal zones of Sri Lanka are evidence for marine transgressions during the mid to late Holocene. Similarly, several inland buried coral deposits found in the SW coasts and many locations in the southern coasts are a few kilometers from the current shore line and are also evidence for marine transgressions (Cooray and Katupotha, 1991; Katupotha, 1995). The shell deposits and gravel deposits of eastern coastal areas also indicative of paleo sea level oscillations. Adikaram et al. (2017) noted fossilized tidal deposits at eastern coasts above $5 \mathrm{~m}$ from the present sea level and suggested a sea level high stand during the Holocene. In addition, the Bolgoda lake area of the western coast and barrier formations of the SE coasts also prove the sea level high stand of the mid to late Holocene (Ranasinghe et al., 2013; Ratnayaka et al., 2017). The maximum height of the sea level high stand is recorded as $6.5 \mathrm{~m}$ (Katupotha and Wijayananda, 1989; Ratnayaka et al., 2017). The marine transgression event of the mid to late Holocene was terminated 3000 years ago when the 
sea level reached its present level (Ranasinghe et al., 2013).

Therefore, it can be concluded that the formations of most sediment barriers in coastal lakes, estuaries and lagoons around Sri Lanka are the result of sea level transgression during mid to late Holocene. Thereafter, fine adjustments of coastal morphologies occurred, with consequent environmental changes throughout the late Holocene.

\section{POTENTIAL EFFECTS FOR MORPHOLOGICAL VARIATIONS ALONG SRI LANKAN COASTLINE}

Sri Lankan's modern coasts are differentiated into four quadrants divided by the four cardinal directions; the coastal environments are discussed in the present study accordingly. The NW quadrant extends from Point Pedro to Chilaw on the western coast, and the SW quadrant extends from Chilaw to Matara (Figure 1). The SE quadrant extends from Matara to Kalmunei (extending southward to Batticaloa Lagoon), and the remaining coastal area of the island makes up the NE quadrant.

\section{GEOLOGICAL AND GEOMORPHOLOGICAL CHARACTERISTICS OF FOUR QUADRANTS}

It is well noted that the NW coast sedimentations can be discussed presuming an identical geological background. This is because the crustal basement of the region is composed of WC rocks and thick deposits of Miocene limestone cover the crustal rocks. Quaternary deposits overlay the
Miocene's, developing a progressive coast (Cooray and Katupotha, 1991). Therefore, Quaternary sedimentation processes of the NW sector typically are controlled by the crystalline rock structures. Most of this quadrant's coastal zone is covered by sediment from the Indian subcontinent, and hence, small islands have distinctive characteristics from the coast. Another characteristic feature of this coastal zone is windblown sand dunes, probably the origin of most of the Quaternary beds since the Pleistocene (Figure 2; Cooray 1984; Dahanayake and Jayawardhana 1979; Jayasingha et al., 2014).

The SW coast of Sri Lanka is known as a regressive coast, and hence, most of the weathered metmorphic rocks are exposed (Cooray and Katupotha, 1991). The world-famous blow hole 'Hummanaya' at Dikwella is a good example of the coastal erosion process which is controlled by geological structures. The basement of the SW coast is composed of $\mathrm{HC}$ and part of the WC. The trend of majority of the crystalline rocks is parallel to the coast line which is able to bare depending on the rock strength against the coastal forces (Figure 3; Kehelpannala, 2003). Rocky, steep cliffs are found in many localities of the SW coasts (Katupotha, 2007).

In contrast to the SW coasts, the SE coast is considered a progressive coast (Cooray and Katupotha, 1991). The Quaternary sedimentation basement of the SE quadrant is VC. Though the southern zones indicate a regressive character, the eastern zones starting from the Panama area indicate huge, 

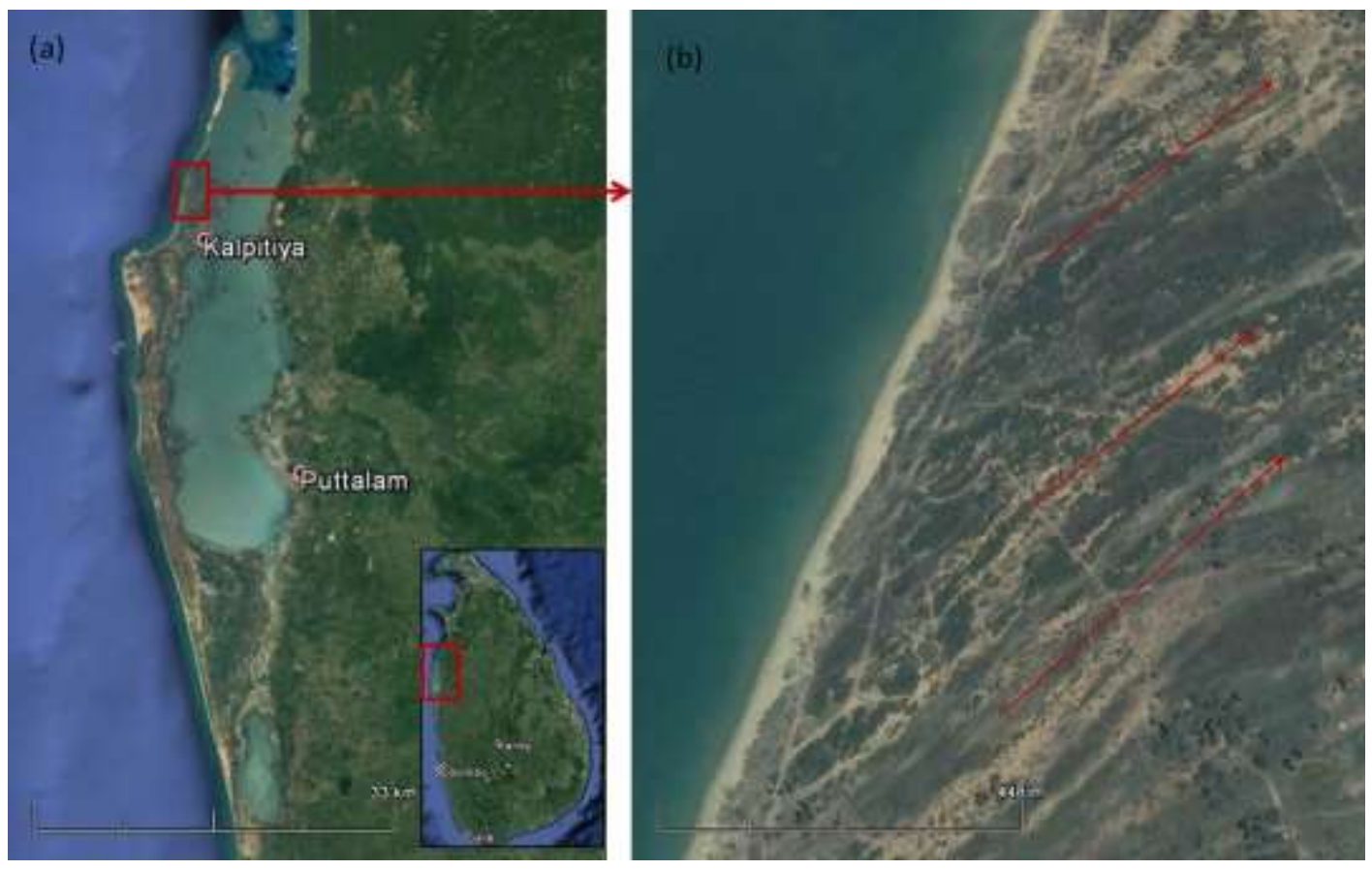

Fig. 2. (a) Development of sand barriers in NW coastal margins (b) Sedimentation is aligned along the wind-blown direction.

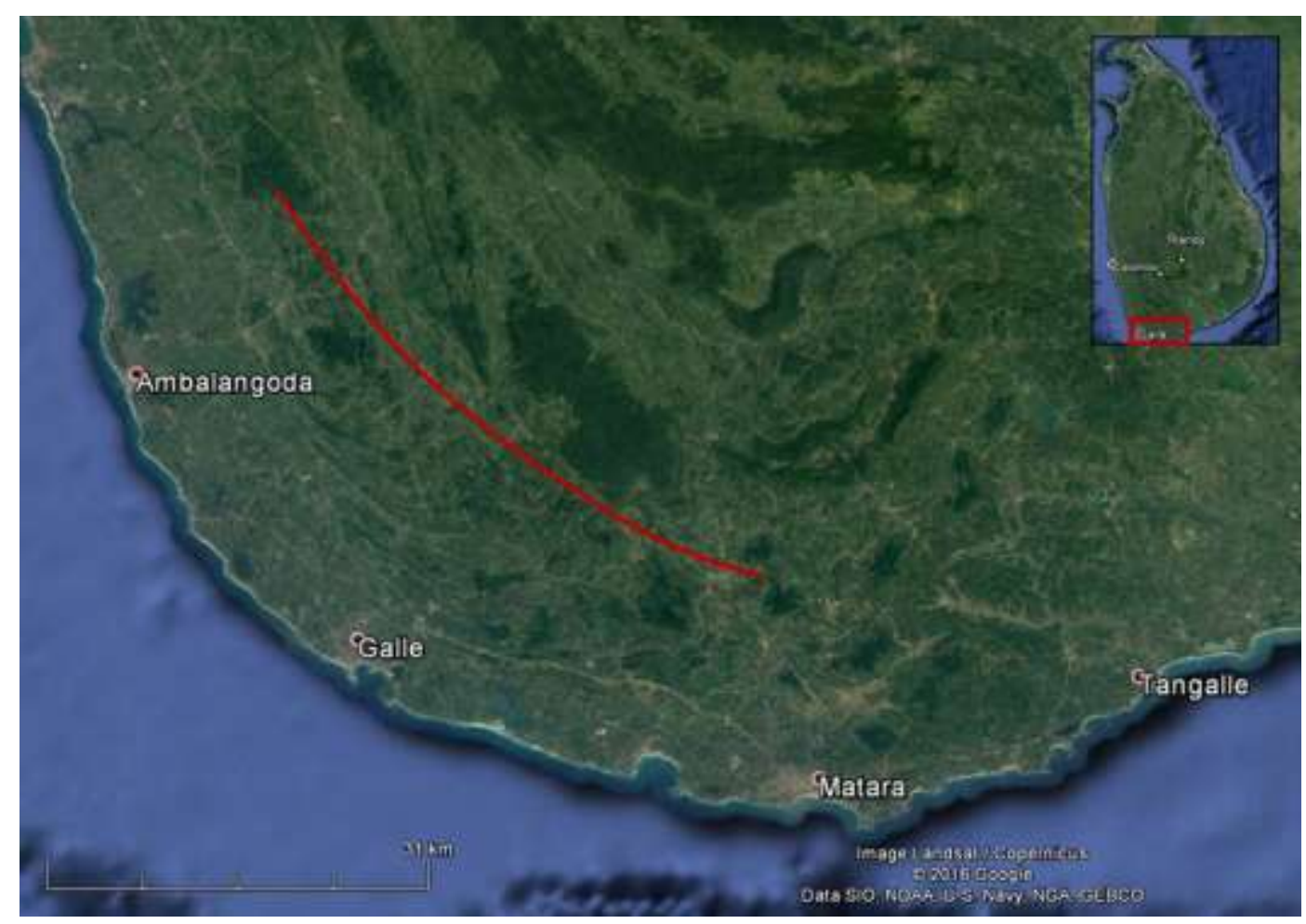

Fig. 3. Southern and SW coasts showing the erosive beaches. The coastline follows the general rock structures (red line indicate the trend of the rocks). 

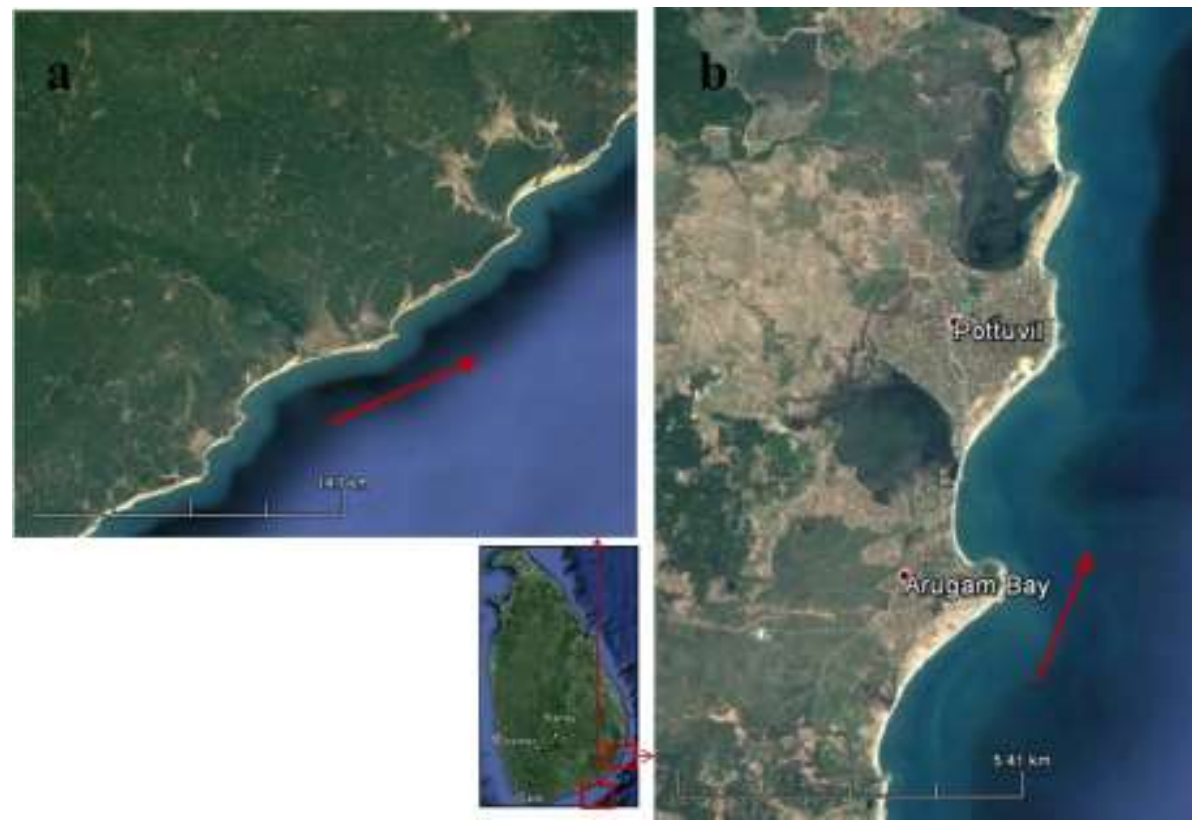

Fig. 4. SE coastal zones (a) development of spits following high energy current paths (b) Sediment deposition along spit.
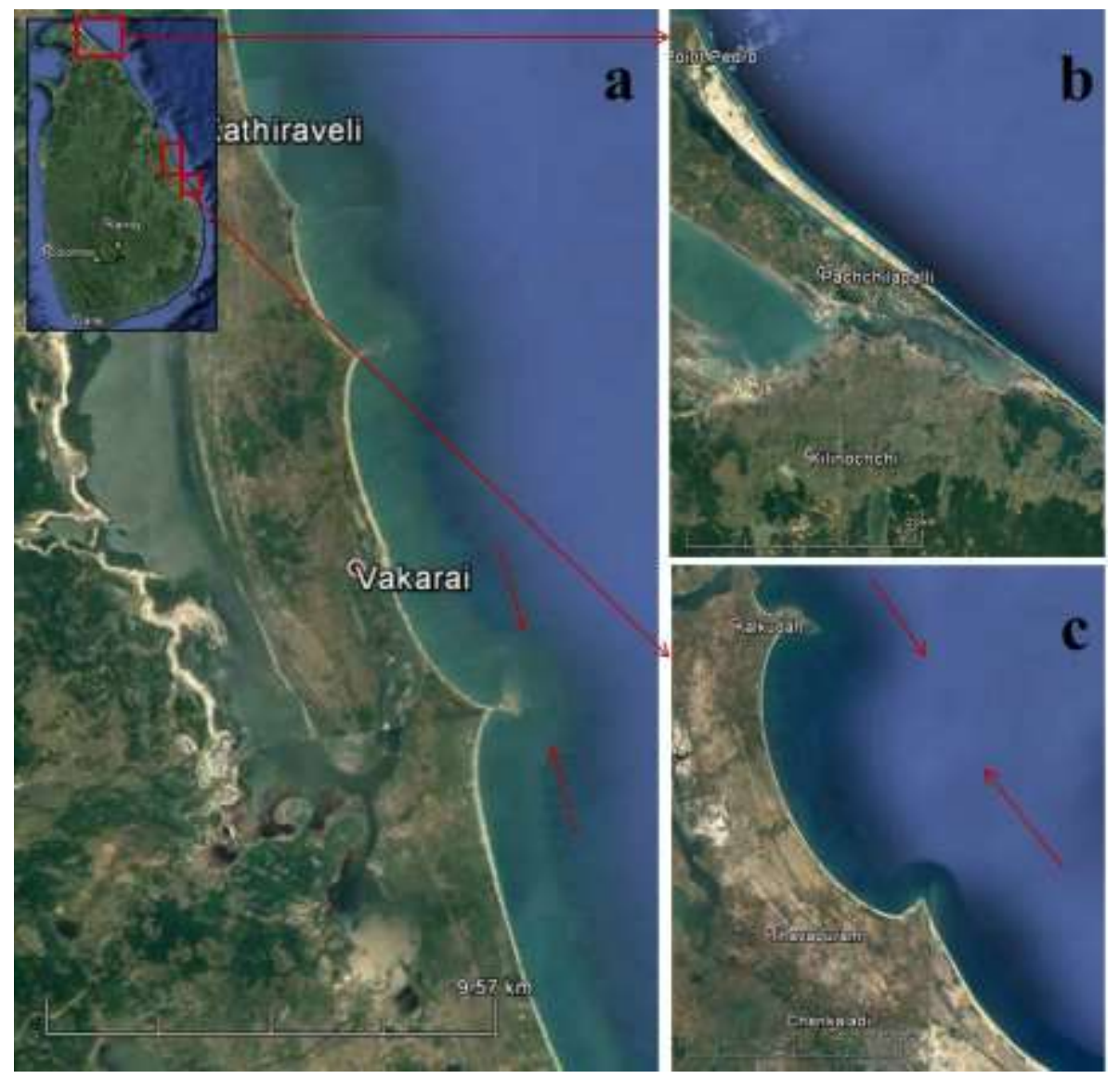

Fig. 5. Selected zones of NE coasts of Sri Lanka. (a) Development of spits indicating longshore depositions and they do not show extensions with current directions. (b) Linear coastline of Jaffna indicating sharpening of coasts from East Indian coastal currents (EICC) (c) Curved beach resulting from wind system. 

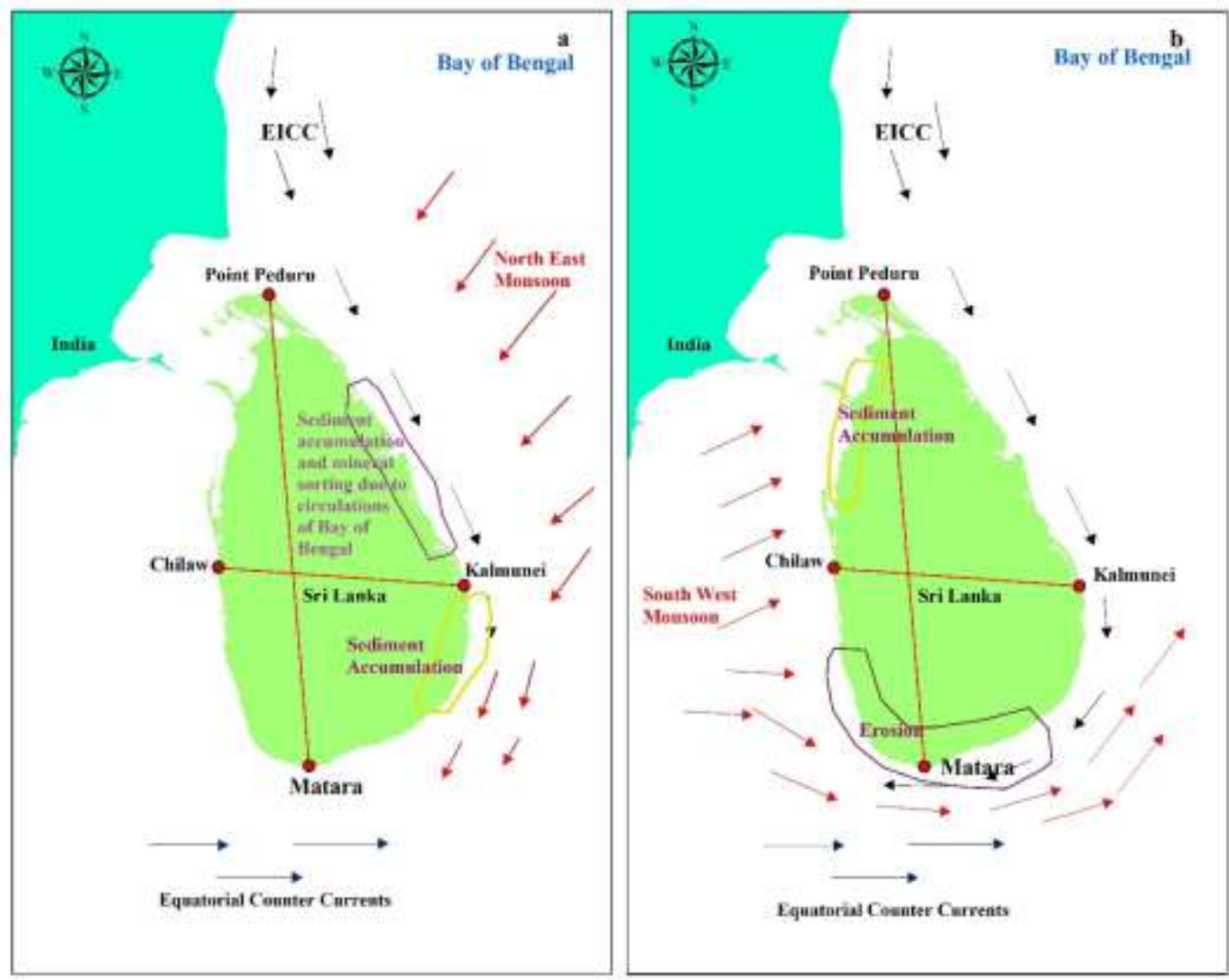

Fig. 6. The paths of the ocean currents that control the coastal evolution of Sri Lanka. Prominent sea current paths during (a) NE monsoons (b) SW monsoons.

progressive sand barriers or spits (Figure 4). Such huge sandy barriers with small dunes cover the old heritage site known as 'MuhuduMahaViharaya', close to Panama.

The NE coasts of Sri Lanka are also a progressive beach, evident from the barrier lagoon formations and sandy coastal planes (Cooray and Katupotha, 1991). This coastal zone is underlined by $\mathrm{VC}$ in the south, $\mathrm{HC}$ in the central part and a Miocene cover at the northern end. The northern portion of Meanwhile, the Gulf of Mannar, in the NW and NE offshores of the Sri Lankan coastline, is characterized by larger fringing reef corals (Rajasuriya et al., 2000). These developed on the limestones and related sedimentary basins, probably favoring shallow marine environments. The bar reef marine sanctuary in the NW coasts is the coast is well known for its mineral sand deposits. Sedimentary geochemical studies of the coastal zone provide evidence of mineral sorting by ocean currents in the Bay of Bengal (Young et al., 2014). In contrast, the Trincomalee area has outcrops of the basement rock. Steep, rocky cliffs are found in the Trincomalee area, which is covered by Highland complex rocks. The southern portion of the coast is covered by massive sedimentary barriers and spits extending towards the Batticaloa (Figure 5).

well extended towards the north, parallel to the coasts. These coral reefs likely acted as a platform for the formation of the islands in the NW coasts. The Hikkaduwa reefs are the healthiest, with living coral cover (Rajasuriya et al., 2000). Shore platforms developed on hard rocks, 
which is favorable for coral growth.

\section{COASTAL PROCESSES MODIFIED THE COASTLINE AROUND SRI LANKA}

The coastal geomorphology of an island such as Sri Lanka is mainly controlled by oceanic processes on the lithology. In particular, a wind driven longshore sediment transport pattern is one of the major factors for a coast to be considered either a progressive or regressive (CERC, 1984). A coast is considered progressive if the erosion rate is less than the deposition rate and regressive if the opposite is true
(Komar, 1998). However, characteristics of the beach face such as the headlands do not deposit longshore sediments and hence can considered regressive coasts.

Geomorphologically, the headlands of the SW coastal zone of Sri Lanka are characterized by well-exposed escarpments and rocky beaches of HC rocks (Swan, 1983). Thus, longshore sediments generated by SW monsoons are not trapped at the SW and southern coasts (Figure 6). On the other hand, the easterly moving currents of SW

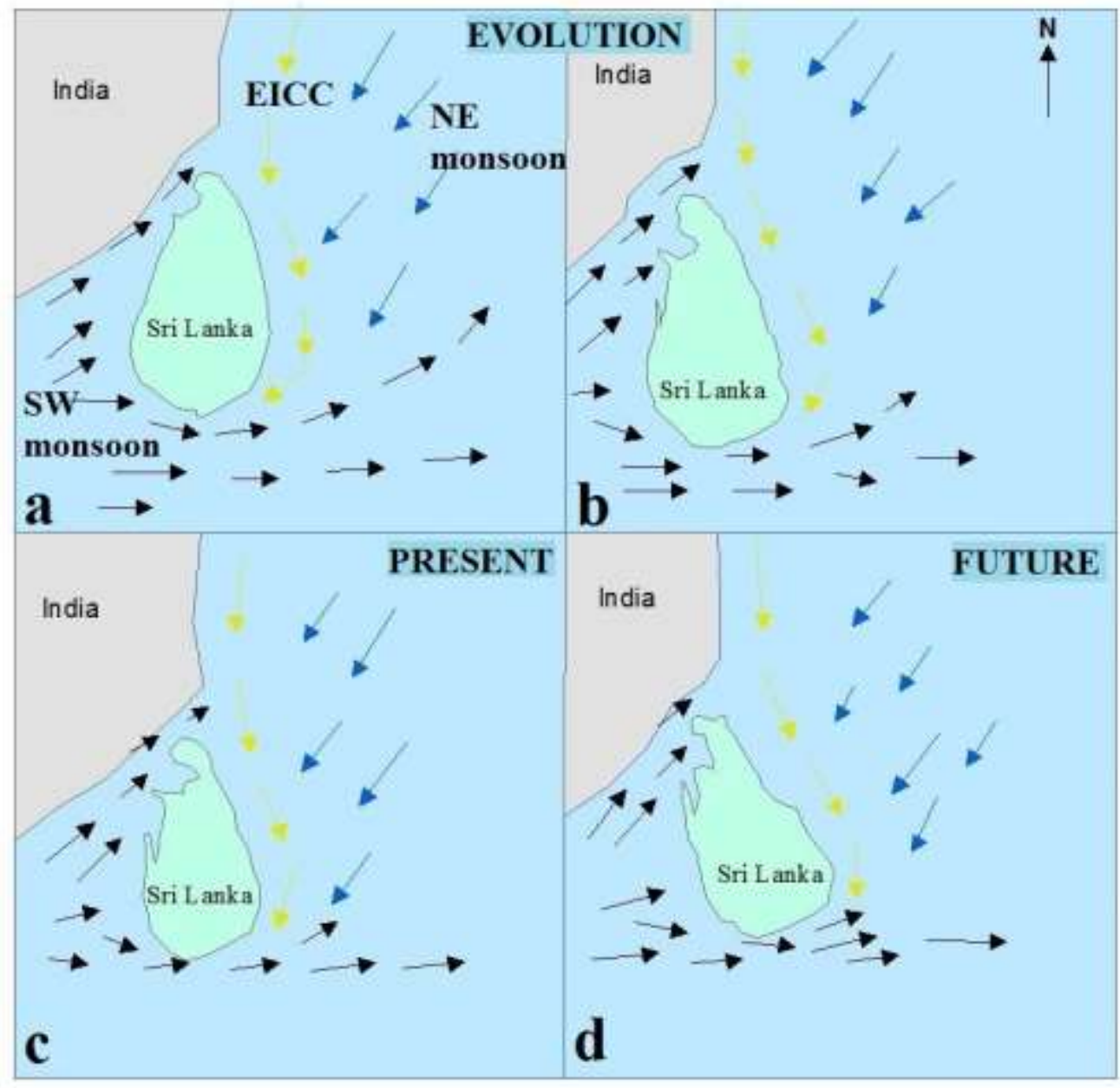

Fig. 7. Hypothetical model for evolution of Sri Lankan coasts; (a) Erosion of NE coast and south - SW coast by EICC and NE monsoon currents and EICC and SW monsoon currents, respectively. (b) Resulted sharp boundary along India-Sri Lanka, (c) Current status of Sri Lankan coasts, (d) Future status of Sri Lankan coasts with well-developed sediment depositions in SE and Negambo area. 
monsoons are complicated and move little away from the Sri Lankan coasts (Schott et al., 1994). A layer of lowsalinity water is coming from the Bay of Bengal and they move towards the West (Schott et al., 1994; Vinayachandran and Yamagata, 1998). As a consequence, the longshore currents driven from the SW monsoons do not deposit sediment along the SW and southern coasts of Sri Lanka. The current path of the SW monsoon changes at the SW coasts of Sri Lanka rather than forming a deposition zone for current generated sediments (Vinayachandran and Yamagata, 1998). Instead, the SW monsoon currents are further energized with westerly wind bursts (WWB) of the world.

However, SW monsoon generated longshore currents travelling to the northern coasts of Sri Lanka or western India are able to deposit the sediments along the NW coastal zones of Sri Lanka. Since the currents generated by SW monsoon are initially broad and become shallow, they can carry a huge sediment load along the continental shelf areas of NW Sri Lanka with advancing the monsoon rains (Vinayachandran and Yamagata, 1998). Further, the identical coastal geomorphologies of NW quadrant of Sri Lanka are fundamentally controlled by the Indian subcontinent and the wide and shallow continental shelf.

Though the geology is similar to that in the SW quadrant, the NE coasts are probably controlled by the rock structure of the basement due to the coastline being perpendicular to the general strike of the rocks or the intensity and patterns of the fracture systems (Hall et al., 2008). In addition, the major controlling factor is monsoon driven circulations of water in the Bay of Bengal. During the NE monsoon, the monsoon currents and east India coastal currents (EICC) flow south along the coastal belt of India and Sri Lanka (Figure 6; Shetye et al., 1996; Mukherjee et al., 2014). Kolla et al. (1976) noted that sediment-bearing wave generated energy move parallel to the coasts of India and Sri Lanka and are able to deposit along the coastal belt. It is probable that the cyclonic activities of the Bay of Bengal also control the sedimentation processes in the NE coasts, and sediments are therefore subjected to the mineral sorting effect. The cyclonic gyre created with the NE monsoons which are activated by the Ekman Pumping cause upwelling sedimentation associated to the SW regions of the Bay of Bengal (Vinayachandran and Yamagata, 1998; Vinayachandran and Mathew, 2003). The sedimentological parameters and the energy variations in such coastal environments are enough to remove the light minerals by winnowing actions (Kulgemeyer et al., 2018). The morphological structures indicate no relative orientation with these circulations (Figure $5 \mathrm{~b}, \mathrm{c}$ ).

In inter-monsoon periods, WWB that have rapid eastward flowing jets are dominant, and hence the energy generated in the coastal currents of the southern coastal zones of Sri Lanka are subjected to erosion rather deposition (Moum et al., 2014). In addition, since the SE coast was aligned in the juxtaposition of the SW monsoon currents and the low-salinity currents of the Bay of Bengal, progressive coasts are recorded in water dilution zones (Figure 6). Above current generated wind forces and the vertical salinity stratifications of this region intensify the suspended sediment loads in the mixing zone of SE region of Sri Lanka (Narvekar and Kumar, 2006). Hence, the energy dilutions in coastal 
zones of SE regions get high sediment loads which can make progressive coasts. Therefore, the eastern part of the SE quadrant shows progressive characteristics, while the southern coasts show regressive characteristics. The eastward flows of SW monsoons and inter-monsoons are stronger than the low-salinity currents of the Bay of Bengal. Hence, the progressive nature of the eastern part is created with welldeveloped spits compared to other coasts (Figure 4). The sediments, likely derived from Indian river systems and rivers in eastern Sri Lanka mixed with low-salinity water currents from the Bay of Bengal and deposited in the eastern zone of the SE quadrant.

The evolution of coastal morphologies around Sri Lanka can be described as shown in Figure 7. In summary, the shape of the island bulges in the NWSE direction and the coastal morphologies were essentially controlled by monsoon forces and regional sea currents. Hidden heritages such as sediment profiles of buried 'Muhudu Maha Viharaya' near Panama of SE coasts will be an ideal location to prove the sedimentation history of Sri Lanka which is useful in environmental and archaeological investigations.

\section{CONCLUSION}

Sri Lanka's coasts yield evidence for a sea level high stand before the LGM. However, the time period for this has not yet been proven. Sea level low stand and monsoon climates during the LGM have provided excessive sedimentation on the coastal planes of Sri Lanka from weathering processes. Hence, Pleistocene coastal morphologies are well developed, with the prevailing climate and sediment supply dominated by fluvial and aeolian actions. During the late
Holocene, Sea-level high-stand is recorded. Subsequently, coastal morphologies have been modified by the geology, geological structures, sea currents and climate of each four cardinal quadrants of the island.

1. The NW quadrant is basically controlled by Miocene limestone deposits with the absence of Precambrian rock structures. The shielding effects of the Indian subcontinent has preserved longshore sediments that come at the beginning of the SW monsoon period. Hence, many islands and sediment barriers are characterized to the zone.

2. The SW and NE quadrants have similar geological conditions but different rock structures. Sea currents from SW monsoons turn around the SW quadrant in a rock strike parallel path. Hence, there are no sedimentation processes.

3. In the southern part of the SE quadrant, the SW monsoon generated sea current flows and westerly wind bursts gave the coast a regressive character. However, the eastern part is the dilution point of sediment bearing freshwater currents from the Bay of Bengal with easterly moving salinity waters and hence sediments are deposited, forming huge sediment barriers.

4. The NE coastal belt is above the sea current nodes and hence sediments loads are reworked with circulations of the Bay of Bengal. Therefore, sorted minerals are common in beaches of the area. 


\section{REFERENCES}

Adikaram, M., Pitawala, A., Ishiga, H. and Jayawardhana, D. (2017) Paleoenvironmental Reconstruction of Quaternary Sedimentation in Eastern Sri Lanka: An Ichnological Study. Journal of Geological Society of India, 89(1): 71-76.

Angulo, R. J., Lessa, G. C. and de Souza, M. C. (2006) A critical review of mid-to lateHolocene sea-level fluctuations on the eastern Brazilian coastline. Quaternary science reviews, 25(5-6): 486-506.

Berger, A.R. and Jayasinghe, N.R. (1976) Precambrian structure and chronology in the Highland Series of Sri Lanka. Precambrian Research, 3: 559-576.

Bird, E.C.F. (1994) Physical setting and geomorphology of coastal lagoons. In: Kjerfve, B. (Ed.), Coastal Lagoon Processes. Elsevier, Amsterdam, pp. 9-40.

Brückner, H. (1989) Late Quaternary shorelines in India. In Late Quaternary sea-level correlation and applications (pp. 169-194). Springer Netherlands.

Camoin, G. F., Colonna, M., Montaggioni, L. F., Casanova, J., Faure, G. and Thomassin, B. A. (1997) Holocene sea level changes and reef development in the southwestern Indian Ocean. Coral Reefs, 16(4): 247259.

Camoin, G. F., Montaggioni, L. F. and Braithwaite, C. J. R. (2004) Late glacial to post glacial sea levels in the Western Indian Ocean. Marine Geology, 206(1): 119-146.

CERC, 1984. Shore Protection Manual. Vols I and II. Coastal Engineering Research Center. U.S. Army Corps of Engineers, Washington, DC: U.S. Government Printing Office, Vicksburg.

Colonna, M., Casanova, J., Dullo, W. C. and Camoin, G. (1996) Sea-level changes and $\delta 180$ record for the past 34,000 yr from Mayotte reef, Indian Ocean. Quaternary Research, 46(3): 335-339.

Cooray, P.G. (1967) An Introduction to the Geology of Sri Lanka. Ceylon National Museum Publication, Colombo, pp 184176.

Cooray, P.G. (1984) An Introduction to the Geology of Sri Lanka. National Museum Sri Lanka Publication, Colombo, pp. 340.

Cooray, P.G. (1994) The Precambrian of Sri Lanka: a historical review. Precambrian Research, 66: 3-18.

Cooray, P.G. and Katupotha J. (1991) Geological evolution of the coastal zone of Sri Lanka. Symposium causes of coastal erosion of Sri Lanka, CCD/GTZ, Colombo, Sri Lanka.

Curray, J.R., Emmel, F.J. and Moore, D.G. (2003) The Bengal fan: morphology, geometry, stratigraphy, history and processes. Marine and Petroleum Geology, 19: 1191-1223.

Dahanayake, K. and Jayawardana, S.K. (1979) Study of red and brown earth deposits of north western Sri Lanka. Journal of Geological Society of India, 20: 433-440.

Deraniyagala, P.E.P. (1958) The Pleistocene of Ceylon. Ceylon Natural Museums Department Publication, Colombo.

Dharmapriya, P.L., Malaviarachchi, S.P.K., Galli, A., Su, B., Subasinghe, N.D. and Dissanayake, C. B. (2015) Rare evidence for formation of garnet + corundum during isobaric cooling of ultrahightemperature metapelites: new insights for retrograde $\mathrm{P}-\mathrm{T}$ trajectory of the Highland Complex, Sri Lanka. Lithos, 200-201: 94-110.

Furstenau, J., Lindhorst, S., Betzler, C. and Hubscher, C. (2010) Submerged reef terraces of the Maldives (Indian Ocean). Geo-Marine Letters, 30: 511-515.

Gardner, R.A.M. (1995). Red dunes and Quaternary palaeoenvironment in India and Sri Lanka. Memories- Geological Society of India, 32: 391-404.

Goff, J., Liu, P. L., Higman, B., Morton, R., Jaffe, B. E., Fernando, H. and Fernando, S. (2006). Sri Lanka field survey after the December 2004 Indian Ocean tsunami. Earthquake Spectra, 22(S3): 155172.

Goto, K., Takahashi, J., Oie, T. and Imamura, F. (2011). Remarkable bathymetric change in the nearshore zone by the 2004 Indian Ocean tsunami: Kirinda Harbor, Sri Lanka. Geomorphology, 127(1-2): $107-$ 116.

Hall, A. M., Hansom, J. D. and Jarvis, J. (2008) Patterns and rates of erosion produced by high energy wave processes on hard rock headlands: The Grind of the Navir, Shetland, Scotland. Marine Geology, 248(1-2): 28-46.

Hanebuth, T., Stattegger, K. and Grootes, P. M. (2000) Rapid flooding of the Sunda Shelf: a late-glacial sea-level record. Science, 288(5468): 1033-1035.

He, X. F., Santosh, M., Tsunogae, T. and Malaviarachchi, S. P. (2016) Early to late Neoproterozoic magmatism and magma mixing-mingling in Sri Lanka: implications for convergent margin processes during Gondwana 
assembly. Gondwana Research, 32: 151180.

Jackson, K.L. (2008) Paleotsunami History Recorded in Holocene Coastal Lagoon Sediments Southeastern Sri Lanka. M.Sc thesis, University of Miami, Florida.

Jayangondaperumal, R. (2014) Teri Red Sands, Tamil Nadu. In Landscapes and landforms of India (pp. 211-216). Springer Netherlands.

Jayangondaperumal, R., Murari, M. K., Sivasubramanian, P., Chandrasekar, N. and Singhvi, A. K. (2012) Luminescence dating of fluvial and coastal red sediments in the SE coast, India, and implications for paleoenvironmental changes and dune reddening. Quaternary Research, 77(3): 468-481.

Jayasingha, P., Pitawala, A. and Dharmagunawardhane, H. A. (2014) Evolution of coastal sandy aquifer system in Kalpitiya peninsula, Sri Lanka: sedimentological and geochemical approach. Environmental Earth Sciences, 71(11): 4925-4937.

Katupotha, J. (1988) Coast and shelf evolution of Sri Lanka in the Quaternary. Extended Abstract. In International Symposium on 'Coastal evolution in the Quaternary: Past and Future', IGCP Project 274, 65-67.

Katupotha, J. (1995) Evolution and geological significance of Holocene emerged shell beds on the southern coastal zone of Sri Lanka. Journal of Coastal Research, 11: 1042-1061.

Katupotha, J. and Dias, P. (2001) Geological evolution correlated to the stratigraphy of the Kalpitiya peninsula. Journal of Indian Association Sedimentologists, 20: 21-37.

Katupotha, J. and Fujiwara, K. (1988) Holocene sea level change on the Southwest and South coasts of Sri Lanka. Palaeogeography, Palaeoclimate, Palaeoecology, 68: 189-203.

Katupotha, J. and Wijayananda, N.P. (1989) Chronology of land shell deposits on the southern coast of Sri Lanka. Quaternary Research, 32 (1): 222-228.

Katupotha, K.N.J. (2007) (Coastal Landforms) The National Atlas of Sri Lanka, Second Edition, Survey Department of Sri Lanka. pp. 40-42.

Katz, M. B. (1978) Tectonic evolution of the Archaean granulite facies belt of Sri Lanka-South India. Geological Society of India, 19(5): 185-205.

Kehelpannala, K.V.W. (1997) Deformation of a high-grade Gondwana fragment, Sri Lanka. Gondwana Research, 1: 47-68.
Kehelpannala, K.V.W. (2003) Structural evolution of the middle to lower crust in Sri Lanka-a review. Journal of the Geological Society of Sri Lanka, 11: 4586.

Kolla, V., Moore, D. G. and Curray, J. R. (1976) Recent bottom-current activity in the deep western Bay of Bengal. Marine Geology, 21(4): 255-270.

Komar P.D. (1998) Beach processes and sedimentation. New Jersey: Prentice-Hall.

Kröner, A., Cooray, P.G. and Vitanage, P.W. (1991) Lithotectonic subdivision of the Precambrian basement in Sri Lanka. In: Kröner, A. (Ed.), The Crystalline Crust of Sri Lanka, Part I. Summary of Research of the German-Sri Lankan Consortium, Geological Survey. Department Sri Lanka Professional. Paper 5, pp. 5-21.

Kröner, A., Kehelpannala, K.V.W. and Hegner, E. (2003) ca. 700-1000 Ma magmatic events and grenvillian-age deformation in Sri Lanka: relevance for Rodinia supercontinent formation and dispersal, and Gondwana amalgamation. Journal of Asian Earth Sciences, 22: 279 300.

Kröner, A., Rojas-Agramonte, Y., Kehelpannala, K.V.W., Zack, T., Hegner, E., Geng, H.Y., Wong, J. and Barth, M. (2013) Age, Nd-Hf isotopes, and geochemistry of the Vijayan Complex of eastern and southern Sri Lanka: a Grenville-age magmatic arc of unknown derivation. Precambrian Research, 234: 288-321.

Kröner, A., Williams, I. S., Compston, W., Baur, N., Vitanage, P. W. and Perera, L. R. K. (1987) Zircon ion microprobe dating of high-grade rocks in Sri Lanka. The Journal of Geology, 95(6): 775-791.

Kulgemeyer, T., Bryan, K. R. and von Dobeneck, T. (2018) Formation of coastparallel heavy mineral enrichments investigated by exploratory numerical modelling. Geological Society of America Bulletin.

Leonard, N. D., Welsh, K. J., Clark, T. R., Feng, Y. X., Pandolfi, J. M. and Zhao, J. X. (2018). New evidence for "far-field" Holocene sea level oscillations and links to global climate records. Earth and Planetary Science Letters, 487: 67-73.

Martin, L. and Dominguez, J.M. (1994) Geological history of coastal lagoons. In: Kjerfve, B. (Ed.), Coastal Lagoon Processes. Elsevier, Amsterdam, pp. 4168. 
Milisenda, C. C., Liew, T. C., Hofmann, A. W. and Kröner, A. (1988) Isotopic mapping of age provinces in Precambrian highgrade terrains: Sri Lanka. The Journal of Geology, 96(5): 608-615.

Milisenda, C. C., Liewa, T. C., Hofmanna, A. W. and Köhler, H. (1994) Nd isotopic mapping of the Sri Lanka basement: update, and additional constraints from $\mathrm{Sr}$ isotopes. Precambrian Research, 66(1-4): 95-110.

Moum, J. N., de Szoeke, S. P., Smyth, W. D., Edson, J. B., DeWitt, H. L., Moulin, A. J. and Fairall, C. W. (2014) Air-sea interactions from westerly wind bursts during the November 2011 MJO in the Indian Ocean. Bulletin of the American Meteorological Society, 95(8): 1185-1199.

Mukherjee, A., Shankar, D., Fernando, V., Amol, P., Aparna, S. G., Fernandes, R. and Gaonkar, M. G. (2014) Observed seasonal and intraseasonal variability of the East India Coastal Current on the continental slope. Journal of Earth System Science, 123(6): 1197-1232.

Narvekar, J. and Kumar, S. P. (2006) Seasonal variability of the mixed layer in the central Bay of Bengal and associated changes in nutrients and chlorophyll. Deep Sea Research Part I: Oceanographic Research Papers, 53(5): 820-835.

Rajasuriya, A., Zahir, H., Muley, E.V., Subramanian, B.R., Venkataraman, K., Wafar, M.V. M., Khan, S.M.M.H. and Whittingham, E. (2000) Status of Coral Reefs in South Asia: Bangladesh, India, Maldives and Sri Lanka. In C. Wilkinson (Ed.) Status of Coral Reefs of the World: 2000, pp. 95 116, Australian Institute of Marine Sciences.

Ranasinghe, P. N., Ortiz, J. D., Moore, A. L., McAdoo, B., Wells, N., Siriwardana, C. H. E. R. and Wijesundara, D. T. D. S. (2013) Mid-Late Holocene coastal environmental changes in southeastern Sri Lanka: New evidence for sea level variations in southern Bay of Bengal. Quaternary International, 298: 2036.

Rao, K. N, Rao, C.U.B., Prakash, P.V. and Reddy, K.T. (2006) Morphostratigraphy and evolution of the Quaternary red sands near Bhimunipatnam, east coast of India. Journal of Geological Society of India, 68: 857-873.

Ratnayake, A. S., Sampei, Y., Ratnayake, N. P. and Roser, B. P. (2017) Middle to late Holocene environmental changes in the depositional system of the tropical brackish Bolgoda Lake, coastal southwest
Sri Lanka. Palaeogeography, Palaeoclimatology, Palaeoecology, 465: 122-137.

Richmond, B. M., Jaffe, B. E., Gelfenbaum, G. and Morton, R. A. (2006) Geologic impacts of the 2004 Indian Ocean tsunami on Indonesia, Sri Lanka, and the Maldives. Zeitschrift für Geomorphologie, 146: 235-251.

Roy, A. B. and Chatterjee, A. (2015) Tectonic framework and evolutionary history of the Bengal Basin in the Indian subcontinent. Current Science, 109(2): 271.

Santosh, M., Tsunogae, T., Malaviarachchi, S.P.K., Zhang, Z.M., Ding, H.X., Tang, L. and Dharmapriya, P.L. (2014) Neoproterozoic crustal evolution in Sri Lanka: insights from petrologic, geochemical and zircon $\mathrm{U}-\mathrm{Pb}$ and $\mathrm{Lu}-\mathrm{Hf}$ isotopic data and implications for Gondwana assembly. Precambrian Research, 255: 1-29.

Schott, F., Reppin, J., Fischer, J. and Quadfasel, D. (1994) Currents and transports of the Monsoon Current south of Sri Lanka. Journal of Geophysical Research: Oceans, 99(C12): 25127-25141.

Shetye, S. R., Gouveia, A. D., Shankar, D., Shenoi, S. S. C., Vinayachandran, P. N., Sundar, D. and Nampoothiri, G. (1996) Hydrography and circulation in the western Bay of Bengal during the northeast monsoon. Journal of Geophysical Research: Oceans, 101(C6): 14011-14025.

Singhvi, A.K., Deraniyagala, S.U. and Sengupta, D. (1986) Thermoluminescence dating of wuaternary red-sand beds: a case study of coastal dunes in Sri Lanka. Earth and Planetary Science Letters, 80 (1): 139-144.

Srivastava, P., Sangode, S. J., Parmar, N., Meshram, D. C., Jadhav, P. and Singhvi, A. K. (2016) Mineral magnetic characteristics of the late Quaternary coastal red sands of Bheemuni, East Coast (India). Journal of Applied Geophysics, 134: 77-88

Swan, B. (1983) An introduction to coastal geomorphology of Sri Lanka. A publication of the national museum of Sri Lanka, Sri Lanka, p 182.

Vinayachandran, P. N. and Mathew, S. (2003) Phytoplankton bloom in the Bay of Bengal during the northeast monsoon and its intensification by cyclones. Geophysical Research Letters, 30(11). 
Vinayachandran, P. N. and Yamagata, T. (1998) Monsoon response of the sea around Sri Lanka: generation of thermal domesand anticyclonic vortices. Journal of Physical Oceanography, 28(10): 19461960.

Vitanage, P.W. (1972) Post-Precambrian uplift and regional neotectonic movements in Ceylon. In: 24th Int. Geol. Congr., Montreal, Sect. 3, pp. 642-654.

Wang, X. and Liu, P. L. F. (2007) Numerical simulations of the 2004 Indian Ocean tsunamis - coastal effects. Journal of Earthquake and Tsunami, 1(03): 273-297.

Weerakkody, U. (1988) Mid-Holocene sea level changes in Sri Lanka. Journal of Natural Science Council, Sri Lanka, 16(1): 23-37.

Weerakkody, U. (1992) The Holocene coasts of Sri Lanka. The Geographical Journal, 158(3): 300-305.

Wickramagamage, P. (2011) Evolution of the Kalu Ganga-Bolgoda Ganga flood plain system, Sri Lanka. Journal of the Geological Society of Sri Lanka, 14(1): 41-53.

Wicramarathne, W.S., Ranathunga, N.G. and Wijayananda, N.P. (1988) Continental shelf sediments of western Sri Lanka. Proceedings of 44th annual sessions of SLASS, Part 1, p 135.
Wijayananda, N.P. (1994) A note on the continental shelf sediments around Sri Lanka. Journal of Geological Society of Sri Lanka, 5: 135-139.

Wilson, D. J., Galy, A., Piotrowski, A. M. and Banakar, V. K. (2015) Quaternary climate modulation of $\mathrm{Pb}$ isotopes in the deep Indian Ocean linked to the Himalayan chemical weathering. Earth and Planetary Science Letters, 424: 256-268.

Woodruff, D.S. (2010) Biogeography and conservation in Southeast Asia: how 2.7 million years of repeated environmental fluctuations affected today's patterns and the future of the remaining refugial-phase biodiversity. Biodiversity and Conservation, 19: 919-941.

Yokoyama, Y., Lambeck, K., De Deckker, P., Johnston, P. and Fifield, L.K. (2000) Timing of the last Glacial Maximum from observed sea level minima. Nature, 406: $713-716$.

Young, S. M., Ishiga, H., Roser, B. P. and Pitawala, A. (2014) Geochemistry of sediments in three sectors of Trincomalee Bay, Sri Lanka: provenance, modifying factors and present environmental status. Journal of soils and sediments, 14 (1):204-217. 